\title{
POLGÁRI LAKÁSKULTÚRA (BOURGEOIS FURNISHINGS) AND A POSTSOCIALIST MIDDLE CLASS IN HUNGARY
}

\author{
KRISZTINA FEHÉRVÁRY \\ University of Michigan \\ Ann Arbor, MI, USA
}

\begin{abstract}
This article looks at the fate of the kind of home furnishing in Hungary known as "bourgeois" (polgári lakáskultúra) as a way to investigate the middle classes that have emerged since the fall of state socialism. In the 1990s, political discourse was full of speculation about the revitalization of a historic bourgeoisie, and the media regularly featured the material culture of such a historic class. Such furnishings were indeed highly valued among an urban intelligentsia, and seemed to represent evidence of a long history of Hungarian bourgeois taste, civilized values and refinement starkly at odds with socialist material culture, tastes and manners. However, I argue that for many of the emerging middle classes in the 1990s and 2000s, this form of furnishing was no longer a suitable expression of the kind of class position to which they aspired, nor for how it was being newly legitimized. As I show through my anthropological fieldwork among the aspiring middle classes in the former "socialist" town of Dunaújváros, even families who owned such furnishings sold them or demoted them to less prominent places in their homes. Although the socialist state had attempted to devalue inherited, antique furnishings in its promotion of modern lifestyles in the 1960s and 70s, it was not until the end of socialism that such furnishings began to fail to represent middle class respectability. New ideals for such a class were based on entrepreneurial achievements in the present rather than on inherited status, and new home décor was an important way in which this new middle class subjectivity was being constituted.
\end{abstract}

Keywords: bourgeois furnishings [polgári lakáskultúra], postsocialist middle class, material culture, homes, Dunaújváros

The photograph on the next page is of a pediatrician's sitting room in the mid-1990s, a bourgeois interior set within the concrete panel walls of an apartment building in Dunaújváros, Hungary's first socialist, planned "new town". When I took it, I was beginning research on the relationship between interior décor and the emergence of new forms of class distinction in Hungary after the collapse of socialism. I had spent a fair amount of time in this room on various visits during the 1970s and 1980s, celebrating reunions or someone's Name Day sipping champagne out of tiny crystal glasses. A Persian rug covered the parquet 


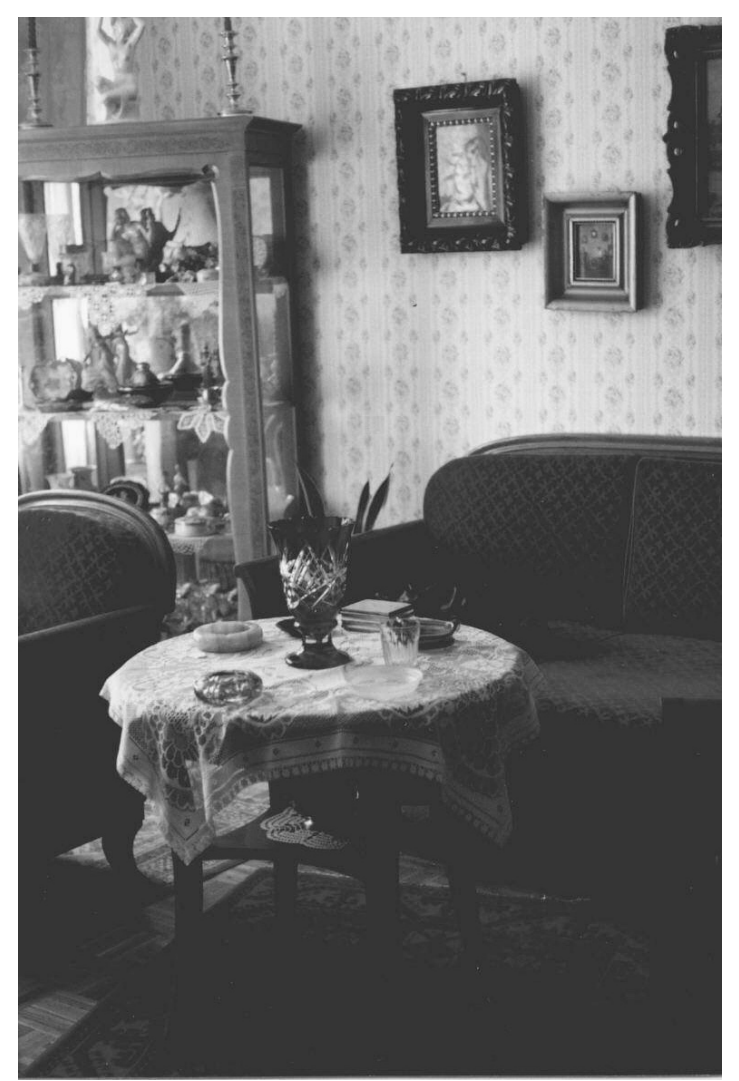

Figure 1. Interior of a Panel Construction Apartment in Dunaújváros, 1994.

Photo by Author

floor and was topped by two armchairs and a sofa upholstered in deep-red velvet, a bit worn, that were placed around an inlaid, sitting room table. Nearby was a matching bureau decorated with porcelain figures on lace doilies, and a display cabinet or vitrin filled the corner. A full-length lace curtain let in filtered light through the large plate-glass window, and plants were arrayed on pedestals in front of it. This "room" had not changed much in those decades, even though it had been moved out of a téglaház, the name of the higher quality brick buildings built during the Stalinist 1950s, and into this newer building of concrete panel construction (hereafter "panel"). It was in photographing the room that I first noticed that the largest painting was a distant echo of the room itself. Enclosed by an ornate frame, it rendered the shadowy interior of a 19th century sitting room, similarly furnished with dark burgundy velvet chairs, an inlaid table and a Persian carpet. The painter had included a shawl draped casually over a footstool, giving the room an inviting and lived-in feel, despite its old-world formality. But instead of 
the cramped, low-ceilinged panel room, these furnishings were in an idealized polgár or gentry interior, with dark wood floors and high ceilings and lit by the natural light of an open French door.

By the mid-1990s, I had become aware of the potent symbolism of this kind of furniture for evoking an historic "polgár" class in Hungary, or bourgeois-citizenry. The term polgár is often translated as the "bourgeoisie", but it is in fact closer to the German word burgher (bürger) as it combines the economic and material associations of a bourgeoisie with the political values of the citizen. Such a class is not synonymous with a "middle class". As John Lukács has insisted: "The existence of a middle class is a universal, a sociological phenomenon. The existence of the bourgeois, on the other hand, has been a particular phenomenon, a historical reality" that is peculiar to the continent of Europe (Lukács, 1970, 616-17). This article traces the shifting forms of social stratification in Hungary from the 1950 s to the present by focusing on the contradictory fortunes of polgári furnishing - a furnishing style largely associated with such a pre-socialist bourgeois-citizenry and its values, but defined as well by its ostensible difference from the materialities of state socialism and the working classes. "Show me your home, and I'll tell you who you are!" is a common refrain in contemporary commercial media featuring home decorating and renovations, but it was also widely used in the media during the socialist period. Social theorists like Pierre Bourdieu have built elaborate mechanisms showing how, indeed, one's home shapes one's sense of one's place in a domestic division of labor as well as in a wider social hierarchy. Everyday activities and interpolations in the home "produce" persons (Bourdieu, 1977), just as a person's "tastes" serve to classify them within a larger social order (Bourdieu, 1984 [1979]). Moreover, as others have shown, home decorating practices also reflect and constitute political orientations (Auslander, 1996; 2001). And yet, what if a social order is itself undergoing rapid transformation just as the material worlds people live in are being transformed? In this case, how did Hungarians produce themselves and contribute to the transformation of a social order through their domestic material practices in the postsocialist 1990s?

The paper will cover three main topics. First, a bit of history on the socialist state's promotion of a broad "middle strata" based on modern lifestyles rather than inherited status, then the odd trajectory of polgár furnishings (polgári lakáskultúra) from the 1960s to the 1990s; and finally, how all this has been playing out in the socialist new town of Dunaújváros since the end of state socialism. I will argue that despite the widespread interest in a historic polgár class in the 1990 s, and a revival of interest in polgári furnishings among an urban elite, the turn away from such furnishings even by people who claim polgári heritage signals the emergence of a new, middle class focused on self-made, economic success rather than inherited class status. 
This new market was fueled in part by interest from abroad, but also by the renewed political and cultural salience of such a "polgár" class for the future of the country as an independent, democratic nation-state. While living in Újlipótváros in Budapest for several months in 1996, the sector built at the turn of the century and in the interwar era for a primarily Jewish bourgeoisie, mailboxes were regularly stuffed with fliers offering "good money" for people's household antiques.

\section{Wither the Middle Class after Socialism?}

After the fall of state socialism in 1989-90, politicians and intellectuals across the political spectrum assumed that Hungary's future as a nation-state depended upon the emergence of a healthy middle class (középosztály) or bourgeois-citizenry (polgár). Such a class was seen as the defining symbol for a western-style prosperity associated with a free market economy, private property and democratic civil society. Anthropologist Michal Buchowski observed that throughout eastern Europe in the 1990s, a "middle class" was "a concept influenced by teleological ideas of "transformation", one that played a powerful "ideological role in the building of the new liberal political and ideological order" $(2008,49)$. The process of "finding" such an emerging middle class during the social upheaval of the 1990 s became part of the production of such a middle class as well as its legitimization. Social scientists researched consumption habits, income distribution, civic consciousness and activities. Advertisers appealed to the new middle-class consumers they envisioned with formal and informal modes of address. And business-oriented newspaper articles and seminars anxiously attempted to identify the new "heroes of enterprise" - entrepreneurs, bankers, financiers - who might provide "role models for the restructuring of the economy" (Marosán, 1994, 72). While there was little agreement as to what type of person constituted a new Hungarian middle class in the 1990s, the material trappings for such a class were widely publicized in the commercial media and displayed in showrooms, warehouses and DIY stores. Meanwhile, people who considered themselves to have belonged to a respectable middle stratum (középréteg) during the socialist decades, struggled to reposition themselves as such in the new order.

These three terms - középréteg, polgár, középosztály - were often used interchangeably, but there were considerable differences between them. The very use of the term "middle class" or középosztály was a new phenomenon, especially in political discourse. Openly advocating the interests of such a class acknowledged the legitimacy of economic inequalities in a capitalist system, but it left open the kind of class structure that was to be developed. Some politicians, however, also drew on various strains of dissident, socialist-era discourses idealizing embourgeoisment or polgárosodás, and in so doing presented competing definitions 
of the ideal citizens they claimed to represent. As we will see, this strategy of referring to a historic middle class was complicated in a number of ways, from how intellectuals had resurrected such a bourgeois category in the last decade of the socialist period to the uncertain status and divided composition of such a class itself in Hungary from the 1870 s to the interwar era. In the following, I briefly sketch out the parameters of these categories as they were understood and deployed as meaningful icons in the 1990s. I show how much these categories depended upon how they were "materialized" in particular material environments and furnishing aesthetics, and how these materialities were in turn seen to constitute the kinds of people being imagined.

\section{Middle Stratum and Bourgeois-citizen during Socialism}

\section{Middle Stratum or középréteg}

A broad-based "middle stratum" (középréteg) began to emerge in the 1960s in Hungary that had much in common with the postwar consumer middle classes in the United States. Sociologists used the term "middle stratum" to distinguish this emerging population from the capitalist middle classes, further subdividing this stratum by a family's position, income and modern consumer lifestyles. In some respects, this distinction can be justified - given that the means of production was largely controlled by the state, no segment of the population owned much capital, and the population enjoying this modern lifestyle included as much of the skilled working class as it did white-collar professionals and Party elites. However, the distinguishing factors of such a population were not so different from the middle classes that emerged in the Euro-American west in the postwar 1950s and 1960s, many of whom were employees of the state or of businesses, and thus owned little "capital" or "means of production". Similarly, many of this postwar middle class were members of the skilled working classes who were able to "consume" their way into the middle classes.

Moreover, this middle stratum was an explicit goal of the state's modernizing projects. Even in the Stalinist 1950s, when the regime was targeting the "polgári" or bourgeois classes as class enemies, industrialization campaigns included programs designed to civilize "backward" populations into a modern, urban working class - through modern apartments but also through literacy campaigns and decidedly "bourgeois" cultural programs (theater, classical music, ballet). By the 1960s of the Kádár era, the socialist state actively promoted the consumption of modern furnishings, labor-saving appliances, consumer goods, and new standards for hygiene. In Hungary as elsewhere in the Soviet bloc, the material forms of these new environments and consumer goods were to "transform" Hungarians into 
modern, future-oriented citizens, and in the process turn them away from the norms of an old-fashioned bourgeoisie. New, urban apartments and modern furnishings were privileged as the paradigmatic living environment of the "contemporary man". In political rhetoric, newspaper editorials, women's journals and film clips, taste makers admonished the growing population moving into these small spaces to get rid of their beloved traditional furniture sets. These were now derided as heavy and dark, burdened with the past, and inappropriate for the modern apartment. "Modern" citizens were to replace them with modern, mass-produced multifunctional designs (or home-made versions of the same if they were unavailable in state shops). A particularly strident version of this new furnishing style was offered in the Dunaújvárosi Hírlap in an article entitled "What should, and should NOT be in the new apartment" (Bars, 1963). If new modern furnishings were too expensive or unavailable, the home decorating magazine Lakáskultúra provided tips on how to make alterations to one's old furniture to modernize them, like removing the carved legs of wardrobes and replacing them with geometric pegs, or to exchange ornate carved, gilt picture frames and replace them with stark, simple frames.

Campaigns to modernize the population also tried to inculcate expectations for new, more demanding standards of living and a discerning consumerism. "Legyen igényes!" or "Be more demanding!" was a common theme throughout the 1960s and into the 1970s. The term igényes has no adequate translation in English, but is a positive term that is roughly equivalent to having demanding standards or requirements for one's material environment, dress and cleanliness. The normative importance of being materially demanding, of having high standards for the care given to one's surroundings and appearance had long been a way of constructing respectability among the well-to-do peasantry. Being "rendes" or proper and orderly, was a defining characteristic of the villagers Edít Fél and Tamás Hofer describe as "proper peasants" (rendes parasztok) in their ethnography of village life in the 1950s (Fél and Hofer, 1969).

Sociologist Zsuzsa Ferge (after Halbwachs) traced the importance of raising the needs or demands of the population to early socialist concerns that the working class and poor peasantry lacked aspirations and were habituated to living with a bare minimum (Ferge, 1979, 309-19). In Bourdieu's terms, they "knew their place". The goal was to elevate the lower classes to the level of an ideal socialist citizenry by expanding their sense of entitlement. Instilling the "down-trodden" with higher levels of "need" was seen as important both to disrupt class hierarchies and as part of a broader modernization and enculturation project. Indeed, this was the objective of the home furnishing magazine Lakáskultúra (literally, "dwelling culture"), according to Mária Pataki, the writer who was its founding editor in the mid-1960s (Interview, September 1997). The material environment, 
especially of the home, was understood to be critical to such social transformations.

In the 1960s, professional elites were expanding the notion of being igényes to include the modernity of one's material environment. Being igényes now required educated appraisal and appropriation of the ever-changing modern world of commodities as an essential part of one's material order and well-being. For example, in an article on new pots and pans in Lakáskultúra in 1967, readers were told that: "Our living conditions and lifestyle often cannot keep pace with our changing demands, but the reverse is also common: Our demands do not change as fast as the lifestyles new technological innovations make possible." The author suggests that the population needed to learn to appreciate and in turn be transformed by the state's advanced technological capacity, such as pressure cookers that would save time and light-weight aluminum pans that would reduce burning accidents. To be a modern, cultured person, citizens were to keep abreast of technologies, design innovations and even fashions, striving to incorporate them into his or her own life:

Every day, contemporary objects produced with up-to-date technology and design come into circulation. [...] Cultured dining, table setting, and serving is not a secondary question for home culture. Let us be more demanding and instruct our family members to be so. Let us follow novel things with attention (D., 1967).

For many urban Hungarians, especially of younger generations, these "modern" goods became desirable indexes of modern identities, but not necessarily of identities as citizens of a Soviet satellite. They were aware of the popularity of modern architecture and furnishings in western Europe and even in the United States, as governments put up thousands of blocks of concrete apartments to house growing urban populations and companies like IKEA rose to furnish them. The new ideal of the "Contemporary Man" linked Hungarian tastes to a Swedish modern style rather than to a Soviet one.

By the 1970s, a widening middle stratum in Hungary had expectations for the lifestyle made possible by an urban apartment, a television, and modern appliances like a refrigerator and washing machine; for occasional cultural outings and vacations; and for a weekend cottage in the countryside. And indeed, the state-run media explicitly encouraged comparison of this lifestyle, presented as a benefit of living in a socialist state, with that of average citizens in the west. However, even as the state heavily promoted modern living spaces and the kinds of modern, civilized socialist citizens they were to produce, the realities of state financing and production capacities meant that this modern lifestyle could not be extended to everyone. Modern furniture was often hard to come by, expensive and of shoddy quality. Because of chronic housing shortages, the socialist state from 1960 on 
followed a policy that encouraged private house building in rural areas, usually by a reciprocal exchange of labor (kaláka). While these houses were progressively "modernized" by the people building them, they continued to be associated with the provincialism of the countryside and of manual labor. With the exception of particular areas of new, detached housing in larger cities in the 1980s, such houses never gained the status of urban respectability. This middle stratum culture, as a result, followed the pattern of middle-class culture more generally in positioning itself as the moral middle "between high and low" (Frykman and Löfgren, 1987; Liechty, 2003). A modern, middle stratum was discursively positioned between an uncouth proletariat, backward peasants and poor Roma (gypsies) on the one hand, and the remnants of an old-fashioned bourgeoisie or déclassé gentry on the other. The market reforms of the Kádár regime also had consequences for social stratification. Material benefits for skilled-labor, management and white-collar workers, and the profits generated by second-economy activities, resulted in economic inequalities and the emergence of new systems of distinction (S. Nagy 1987).

\section{The Contradictory Fate of the Polgár during Socialism}

During the early years of the Stalinist era, members of a polgár class and particularly those that had been involved in businesses large or small were targeted as enemies of the people and persecuted. Traces of polgári lifestyle, vocation, manner of speaking, dress and furnishings were politicized and could be used as evidence that a person was predisposed to be against a redistributive type of economy (Rév, 1991). An architectural draftsman in Dunaújváros who had come from a rural working class family remembered how during this time, wearing creased pants to work could be read as a sign of political unreliability. Though the regime fairly successfully disrupted the material basis for traditional class hierarchies, terms like polgár or kispolgár (petty bourgeois) lived on as cultural categories with complicated meanings. Once the Kádár era reforms were underway in the early 1960 s, the orientations of state media, factory production and professional "taste makers" towards what were considered polgári furnishings and objects were full of contradictions.

Despite the promotion of a modern, "contemporary style" and a communist intelligentsia's derision of "bourgeois kitsch", the state production and retail sector nonetheless actively sold and promoted régi or "old/antique" furnishings, often in the same publications that advocated the superiority of the modern. Many Party bureaucrats and cultural producers had tastes which varied significantly from the monochromatic functionalism that dominated design discourse throughout the Soviet bloc in the 1960s (Crowley and Reid, 2000; S. Nagy, 1997; Veenis, 1999). 
Others were aware of the tastes of the general public and wanted to provide them with goods they actually desired. Factories also produced furniture and decorative objects entirely out of keeping with the "contemporary style". Porcelain factories, for example, manufactured vases with simple, modern shapes and lines, but also figurines such as the popular reproduction of a 19th century stage actress in a ball-gown. In Budapest and elsewhere, workshops were advertised in the late 1960s that not only made reproductions of antique furniture (particularly styles made before 1850), but advertised services to restore or reupholster antique pieces (Lakáskultúra 1967/3, 18-19, 31). And the state consignment warehouses, BÁV (Bizományi Áruház Vállalat) regularly advertised old-fashioned and antique furnishings, many of which they had acquired as the cast-offs of people moving into panel construction apartments who wanted modern furnishings. Lakáskultúra and other publications featured articles on the appropriate combination of "old and new" furniture. In a contest sponsored by Lakáskultúra in 1969, for example, readers were encouraged to cut out examples of antique furnishings and paste them into a line drawing of a "modern" room in a "tasteful" way. A decade earlier, a book on "the home" had provided an explanation for why such antiques were not to be feared:

\begin{abstract}
Today's outlook is experienced and wise enough to combine the most up-to-date interior designs and forms with antiques. The basis for this courage is the acknowledgement that not just the age, form, decoration or technology of an object can be "old", but that arrangements can also be archaic or new and timely. In the furnishings of our day, the point is that there is a new relationship between our useful objects. A contemporary interior design is not dominated by a uniform style at all costs, with furniture of smooth lines and objects that are alike. On the contrary. One does not have to part with objects made, bought or inherited from an older time, even an antique from a century ago, if they are good for our plans and well executed. If we arrange our homes with competence, modern furnishings does not preclude the possibility that a Biedermeier commode or empire secretary might elevate a room's beauty and atmosphere (Bánkuti, 1958, 170-1).
\end{abstract}

More orthodox members of the cultural intelligentsia, however, regularly complained about such production. A journalist in Dunaújváros, for example, railed against the decorative porcelain figurines and lead crystal displayed in a local shop window, asking "Should we be advertising kitsch?" The local head of distribution defended these goods as having been vetted by the highest levels of the Hungarian design establishment. The journalist retorted by accusing state manufacturing entities of defaulting on their "responsibility" to produce material goods that would lead to a socialist future by capitulating to public demand for such ob- 
jects. "The problem of kitsch", he insists, "is not a commercial but a political question... The media is not the tool of commercial advertising... it cannot shirk its duty" [to help society move forward] (Reklámozzuk-e a giccset? Dunaújvárosí Hirlap 7/16/1963).

By the late 1960s, Lakáskultúra also began to feature the apartments of people who lived in "older" settings alongside its usual staple of average Hungarians in modern apartments. These homes belonged to members of a cultural intelligentsia, and the term "régi" or "old" was used instead of polgári. Cultural celebrities like artists, writers, and theater directors were inevitably shown in their high-ceilinged urban interiors furnished with antiques, books, Persian rugs, and original works of art - explained as gifts from friends and fans, rather than as inherited objects. Such professions were understood to have a deep appreciation for the arts but were unencumbered by the material and pragmatic problems of ordinary folk. Possessed by such anti-materialist persons, antiques became objects imbued with history and memories of personal rather than material value - inalienable possessions rather than alienated commodities, as the anthropologist Annette Weiner understood such objects (Weiner, 1985). A variation of these furnishings were also acceptable in the apartments of scholars, categorized as "teacher homes" (S. Nagy, 1987). These pieces featured a journalist, writer or professor's desk, piled high with papers against a backdrop of floor-to-ceiling bookshelves crammed with hardbound volumes. Antique furnishings were never shown in the "inappropriate" settings of panel apartments, but only in older interiors with high ceilings and parquet floors where they were understood to be at home. Like the couple whose story begins this article, however, many families hung on proudly to their polgári interiors even within the confines of modern, panel buildings. Others followed decorating and furnishing advice on how to combine modern furnishings with porcelain decorative statues and other items for the display cabinet (vitrin) - creating a hybrid kind of style Katalin S. Nagy called “quasi-modern" (S. Nagy, 1987).

In the mid-to late 1970s, an urban, dissident intelligentsia turned its attention to the "burgher" values and culture of the pre-socialist period, revaluing it as a form of opposition to the socialist state. While the nationalist-populists agitated for a return of a patriarchal family structure and women's confinement to the domestic sphere (as in West Germany), the liberal opposition, greatly attracted to the theories of Habermas and other writers on civil society, attempted to find in the private public of the second economy the basic form of an autonomous second society. Writers such as György Konrád (1984) proposed that this sphere of autonomy from the state constituted a kind of anti-political civil society. The resulting philosophy of anti-politics was based on the value of "home and free time [...] the spatial and temporal dimension of civic independence", where one's artificial state persona is "not identical" with one's true self and "respect for money and 
property have not undermined other values in the moral consciousness" (Konrád, 1984, 197-202). Nevertheless, an important component of this idealization was based in the aesthetics of the home. Where a modernist avant-garde had once set itself up in opposition to the decadence, pretentions and artifice of a bourgeoisie, now the remains of bourgeois materialities seemed to embody a realm of "beauty" and civilized values set against the ugly genericism of socialist modern architecture and the ostensible duplicity of life under communism. As Iván Szelényi remembers it, "burgher" values and their materialities were rediscovered:

\begin{abstract}
[T]he beautiful homes of "bourgeois intellectuals", where people sipped afternoon tea from fine china in living rooms full of antique furniture, conversing about Proust and Mahler. ... In contrast to the collectivist values promoted by Communism, the autonomy of presocialist burgher intellectuals was emphasized, their sense of irony and humor (so badly lacking among party intellectuals), their loyalty to friends (in contrast to the party loyalty of Communists, who, in principle, should always have been ready to betray personal friends for "the cause"), their unshakable good aesthetic sense (in contrast to the horrors of socialist realism) and so on... (Szelényi et al., 1988, 52-3).
\end{abstract}

Among a cultured intelligentsia, identifying oneself as part of the "bourgeoisie" strangely became a form of resistance. Unsurprisingly, the ascendance of this bourgeois category came with an open devaluation of socialist values and of the working class, a class increasingly associated with an unnatural form of government as well as with characteristics of dependency and lack of initiative. The socialist state itself participated in this shift in class values in the 1980s, through privatizing economic reforms but also by officially recognizing that a small-scale entrepreneurial stratum would "continue to contribute for some time to the life of socialist society". The state attempted to "discipline" the working classes by threatening unemployment while the official media began to depict the proletariat as lazy and shiftless rather than the heroes of socialism.

\title{
Polgárosodás in the 1990s
}

It was only after 1989 that references to a historic middle class or polgár were openly used in politics. Scholarship on the historic polgár and its possible traces in Hungarian culture had been underway in the late 1970s and 1980s as part of the revival of interest in a historic polgár (e. g. Losonczi, 1977; Szelényi et al., 1988), but in the early 1990s the topic was a focus of intellectual activity (see for example Gerő, 1993; Hanák, 1992; Somogyi, 1991). The journal Századvég published a special issue on the topic in 1991, and in 1993 the journal Replika devoted a spe- 
cial section to the question of whether the term 'polgárosodás' was useful for social science research (Sasfi, 1993). It was also a favored topic in politics and in the popular media. Newspapers on either side of the political spectrum regularly published photographs and news articles about a civilized, turn-of-the-century and interwar Hungarian bourgeois-citizenry. These included features with photographs of the historic Hungarian bourgeoisie in their horseless carriages, spacious apartments or semi-urban villas, airy sitting rooms, and Sunday afternoon meals in the garden. The heightened significance of this polgár category stemmed in part from how it had been developed as part of an oppositional discourse during the socialist era. As Judit Bodnár has noted, "the ideological attack on the bourgeoisie effectively made anything 'bourgeois' an element of a desirable past" (Bodnár, 2007, 142). While some of the intelligentsia focused on the Jewish/German industrial classes and their intermarriage with the gentry, in more conservative publications the role of these "foreign" elements was often downplayed or omitted altogether, focusing on the predominantly Magyar population of civil servants. In general though, this "class" was understood to embody an ideal combination of civic consciousness, loyalty to the nation-state, and yet entrepreneurial energy.

Some of the urban intelligentsia hoped that the descendants of a historic polgár or at least their cultural traces would revive latent political and cultural dispositions as much as economic practices. As sociologist Zsuzsa Ferge remarked in a 1997 interview, "the polgár always meant more than money and property ownership... It also embodied culture and life-management (életvitel). The doctor and educator who were not entrepreneurs could also be polgár with a secure existence. This offered them sovereignty and autonomy" (Ferge, 1997, 19). For others, the search for a Hungarian bourgeoisie was motivated by a desire to reveal traces of an autonomous capitalist spirit in contemporary peasant-workers or second-economy entrepreneurs. Like the interwar sociologist Ferenc Erdei, Iván Szelényi followed the lead of Pál Juhász in focusing attention on a small fraction of the peasantry displaying signs of an entrepreneurship that had coexisted with the socialist system, instead of on an urban bourgeoisie. Here, the notion of polgárosodás (embourgeoisment) is used to mean eradicating mentalities of entitlement and dependence on the state, reforming slack work habits, and fostering risk-taking, economic autonomy, entrepreneurial activities, as well as civic responsibility (Szelényi et al., 1988, 22).

At the same time, supporters of a neoliberal left dismissively equated the more conservative parties' obsessions with the polgár as PETTY bourgeois, or kispolgári. For example, in 1998, a public intellectual wrote that public support for the Hungarian Polgár Party was merely an updated version of the political apathy of the state-socialist era, "characterized by the values of the Kádár petty bourgeoisie: quiet material growth, refrigerator, car, Greek vacation, the longing for a 
relatively undisturbed private life, in exchange for relative disinterest in politics" (Dessewffy, 1998). As such, the term became pivotal in endorsing or rejecting varying political and economic positions that might allow such a class to flourish. Indeed, after the mid-1990s victory of the reform Socialist party and its neoliberal coalition partner, the Free Democrats, the dominant opposition party appended its name to include the word for "bourgeois-citizen" or Polgár. In this way, the formerly liberal Young Democrats (FIDESZ) were transformed into a socially-conservative and nationalist but fiscally protectionist Hungarian Polgár Party ( $\mathrm{Ma}$ gyar Polgári Szövetség). These two political factions have defined Hungarian politics since.

As we have seen, the domestic social relations and material trappings of this bourgeois domestic private sphere were a fundamental part of its idealization. The adjective "bourgeois" (polgári), as Bodnár sees it,

does not have much to do with the propertied bourgeoisie; rather, it is used as the incarnation of objects, lifestyles, manners, and arrangements that have been proven solid, efficient, and good. Its natural home is the bourgeois household with its interior dominated by traditional taste and propriety (Bodnár 2007, 142).

The popularity of such patinaed artifacts was bolstered by an international market for the relatively inexpensive heirloom antique furnishings to be found in Hungary. Particularly in Budapest and larger cities, a self-ascribed cultural intelligentsia clamored for such décor, often buying it from second-hand shops or BÁV warehouses if they could not get it from relatives. At a writer's party in Budapest, I saw a young intellectual caress a Biedermeier wardrobe with only half-joking eroticism. Later that year, back in Chicago, I went to see the work of a Hungarian avant-garde video artist, clad from head-to-toe in black. He announced to his perplexed American audience that he was "proud to be bourgeois!" but his documentaries were dreamy compilations of amateur home movies made by Hungarian polgár families, most of them Jewish, from interwar Hungary. As in this artist's documentaries, the reclaimable objects and interiors of this lost class seemed to have the power to conjure its spirit, to produce the kind of social order and person that were being elevated in political discourse and the popular media.

While some politicians and historians were attempting to re-establish the link between polgári furnishings and the surviving embers of such a class, the decorating industry was doing the opposite. It was detaching such objects and interiors from inherited cultural capital and attributing it instead to aesthetic sensibilities that could be acquired. Popular house-design magazines regularly featured apartments with polgári furnishings, and attributed to these interiors not just a way of life but a kind of person. For example, an article published in Lakáskultúra in 1993 featured a turn of the century bourgeois-intelligentsia flat, with antique fur- 
niture, wood floors, bookcases - no televisions or other signs of high tech equipment. Entitled "Polgári apartment - today", it pictures dimly-lit rooms with heavy and dark furnishings that are described as elegant, "puritan" and serious, but also providing a place of security and peace, filled with old family (inherited) objects (Baló, 1993). Another features the more brightly-lit apartment of an intellectual couple with lighter furniture and an eclectic array of objects described as "cosmopolitan", such as a Japanese Buddha but also an antique, carved peasant wardrobe and Hungarian embroidered pillows. The owner is quoted at length about "the history and spirit in old things" and how "they are potentially the source of great joy, particularly if we want to immerse ourselves in their mode of production and the era in which they were born" (Lukovits, 1995, 38).

Central to the narratives was the aesthetic good taste and cultivation of the owner, who was able to recognize objects of value that had been cast aside by others - a Biedermeier bureau covered in grime in a warehouse or a Persian rug being used as a foot rag - and through loving labor had restored these objects to their former luster. Such good taste was not necessarily inherited. The woman who rescued the Persian rug was described as coming from an "uncultured" working class background, but that even as a child she had been drawn to museums and fine art. An autodidact, she had learned about rugs through books. While not inherited, such "taste" nonetheless aligned the qualities of the owner with those of the object. An interior decorator explained the appeal of antiques in a weekly economics magazine in 1996, saying that a particular piece

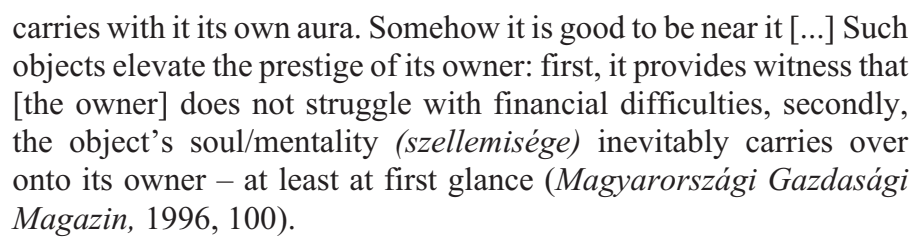

\section{Polgárosodás in Dunaújváros}

In the 1990s, Hungarian citizens who had achieved some semblance of this socialist "middle-class culture", whether through modern furnishings and lifestyles or whether by holding onto furnishings signaling a polgári past, fully expected to constitute the new Hungarian middle class. Instead, most found themselves struggling to "keep up" their social status in the face of economic and institutional upheaval (Fehérváry, 2002; see also Berdahl, 1999, Patico, 2008). My inquiries into polgárosodás in Dunaújváros were met with a shrug of the shoulders or sighs of exaggerated despair. My respondents - many of whom considered themselves to be polgár - claimed there had never been a polgár stratum of any consequence in 
the "city of the proletariat", and the few that chose to stay were technical professionals, not a cultured intelligentsia (humán értelmiség). A woman in her fifties who had been an elementary school teacher in town for decades, remarked on how she truly understood this when she moved back to her home town of Kecskemét, a historic city in the middle of the country. In Dunaújváros, she claimed, people were rude on the street, and children addressed her with the familiar "you" form (te). In Kecskemét, people were more "civilized": a man offered to carry her suitcase, people greeted one another in the street, and children addressed their elders with respect. Without a model polgár in Dunaújváros, consensus among a "respectable" stratum was that there was little hope there would ever be a process of embourgeoisment. This problem was exacerbated by the lack of a pre-socialist "history" in town, except for the old village district that was being extensively renovated. And yet, people who considered themselves as polgár or aspired to polgár manners and values had always existed in the city, and were fairly recognizable by their material culture, dress and general habitus. As we have seen, many families claiming this status had never abandoned inherited polgári furnishings for modern furnishings.

For many of an aspiring middle class in Dunaújváros, however, the celebration of a Hungarian bourgeoisie in the 1990s implied the privileging of those who could claim some form of polgár ancestry, and thus the restoration of a form of social stratification that had been discredited for forty years. Likewise, the resurgence of popularity for polgári furnishings did not find a market in the former socialist city. Instead, contemporary models of a "middle-class" (középosztály) life and ostensibly merit-based social structures to be found in the Euro-American west were far more appealing, and had more continuities with the criteria for members ship of the "middle strata". Most Hungarians were familiar with the (mythical) American model of middle classes based on television, from travel abroad and from books, many of which focused on the late 19th to mid-20th century. A young convert to Mormonism was only one of several people who recommended that I read a paperback bestseller by E. A. Jameson that catalogued the indigent beginnings and exploits of early industrial millionaires (1993 [1920]). When I tried to find this author "Jameson", I discovered the book had first been published in Hungary in 1920 and had recently been reprinted. Another popular book was Daniel J. Boorstin's The Americans, translated into Hungarian in 1991 (Boorstin, 1991 [1974]). A divorced woman in her 40s working at the city museum sought me out as an American to discuss the subject of American values and culture. Her interest had been sparked in part by her conversion to 7 th Day Adventism and its practice of an unmediated, self-reliant reading of the Bible. Weber's The Protestant Ethic and the Spirit of Capitalism had explained much to her, she said, about a western attitude and its role in what Americans and Europeans had been able to achieve, particularly the quality of "hope" and a belief in 
God's help (a Hungarian translation had been published in 1982). But Boorstin had also convinced her that

\begin{abstract}
Americans are beyond concern with material appearances because they went to America in 1620 with the conviction of their Puritan ethic, and built up that land and fought for their freedom, unencumbered by an aristocratic code.
\end{abstract}

She had found this ethic so compelling, that she'd taken up quilting as a distinctly American, productive practice. Another couple, with no polgár in their backgrounds, also mentioned Boorstin's book, but only told me about the top three of the nine layers of American society presented: first, old-name inherited wealth like the Rockefellers; second, those who had some inherited wealth as start-up capital but were otherwise "self-made" through a combination of wits and good fortune, like Bill Gates; and finally, the CEO types who made millions without risking their own capital. In this model of American social life, class-status or family background seemed less relevant than ambition and hard-work (and perhaps unscrupulous behavior) to reach the status of comfortable middle class, or, as in the book on millionaires, to get rich.

I have written elsewhere about how many people of a middle stratum in Dunaújváros resisted the idea of the new, suburban family house because they associated this kind of house with worker peasants and backwards village life (Fehérváry, 2011). For many of this middle strata, the ideal remained to live in the stimulating city environment during the work week, and relax in the fresh air and quiet of a rural cottage and garden on the weekend (Bren, 2002; Caldwell, 2011). By the end of the decade, however, enough new, modern "middle class" houses had been built to form "suburbanizing" neighborhoods in nearby villages. Despite enduring prejudices against such a house form and the difficult economic climate for house building in the 1990s, it became clear that such houses had become a defining sign of new, middle class belonging. They constructed the new middle classes as "autonomous" and "private" but at the same time modern and Hungarian through their materialities. The fate of a polgár ideal can also tell us something about the character of these new middle classes.

In the following cases, two are of couples who had "inherited" polgár status and furnishings and had displayed these in their urban apartments. A third had not had either, but their families had prospered during the socialist era. The parents of this last couple, Edit and Gábor, had risen in status from rural farmer to directorships in the socialist bureaucracy, and lived in a renovated, fully modern apartment in the center of town. Edit's mother had been thrilled when Edit and Gábor had managed to acquire the loft space in the same building she lived in to construct a large apartment with wonderful views. Edit had purchased polgári furni- 
ture to decorate the loft, combining it with a state-of-the-art modern kitchen. But her mother was horrified when they decided to sell the apartment a few years later in order to build a modernized peasant house, or, as the Lakáskultúra feature they showed me called it: "Peasant House in Bourgeois Manner" (parasztház polgári módon). Having herself escaped the backwardness of village life and "made it" in the modern town, she could not fathom why anyone would move back. She could not see that Edit and Gábor were attracted by a new trend: renovating old, peasant houses with state-of-the art conveniences. Having grown up in the polluted, socialist urban environment, they could romanticize Hungarian village life and at the same time bask in the prestige of "cultural preservation". They got rid of their polgári furniture, and replaced it with "authentic" folk pieces alongside of more modern and comfortable leather furniture.

Two other families who moved to suburbanizing neighborhoods in nearby villages, however, did have inherited polgári furnishings, including carpets and art. Eszter and Károly were entrepreneurs in their mid-30s, both on their second marriages, who cashed in all their savings and sold their panel apartments to finance the building of a new family house on the outskirts of a nearby village. Eszter, as the daughter of a medical doctor, had always considered herself entitled to signs of prestigious distinction. Her new husband was a budding entrepreneur, first running a village disco-bar and then opening a "western" used goods store. They both attributed the failures of their previous marriages to differences in social class made manifest in "expectations" for material standards of living (igény) and the drive to achieve such lifestyles. A family house was integral to their understanding of the social position they would occupy in the new Hungary. Like most Dunaújváros residents, Eszter and Károly had lived their entire lives in small, urban apartments. When they married, they had lived in a one-bedroom apartment, furnished with a Biedermeier furniture set inherited from Eszter's grandmother. But when their two-story, four bedroom house was built, Károly insisted that Eszter's valuable Biedermeier furniture be stored upstairs and out of sight. Their house and interior revealed much about their postsocialist class identity. They identified fully with an entrepreneurial, ambitious, risk-taking but hard-working middle-class who they thought would occupy a place of privilege in the new capitalist order. Both had begun their entrepreneurial pursuits in the late $1980 \mathrm{~s}$, before the official fall of state-socialism, and believed its demise would remove the biggest obstacles to their ambitions for private enterprise. The new middle class with which Károly identified was about action rather than intellectualism or culture. Eszter's antique furniture communicated the wrong kind of status: an old-fashioned, out-of-date and inherited status, that said nothing of their success in the present. Their new, modern living room furniture was far less valuable, but it was a much clearer sign of their "self made" prosperity. Moreover, in contrast to the 
formality of older sitting room furniture that required people to sit upright, their soft, modern furnishings allowed for the relaxed and comfortable informality they felt they deserved as hard-working people (Wilk, 1999).

Anna, the daughter of the couple whose apartment we saw at the beginning of this paper was a lawyer in her 40s in the mid-1990s. Considering herself a member of a cultural intelligentsia, Anna was at first vigorously opposed to moving to a family house, understanding the burdens of a house in the village - its isolation, lack of services and spotty public transportation - to fall on the woman's shoulders. More importantly, she could not assimilate the "family house" into her identity as a member of an urban, polgár intelligentsia. Nonetheless, they eventually moved to a house that her husband Tibor, an engineer at a division of the privatizing steel factory, had designed himself and had the construction done under his supervision. The house was equipped with the latest technologies, painted a dark watermelon pink, and had a bricked in patio area and expansive lawn with a high, protective gate around it. The exterior was a modest one-story, but the interior was spacious and well-appointed. Anna's inherited polgári furnishings and art objects, which had been accorded prominent places in her urban apartment, were now relegated to a room with the door closed. They were replaced in the open living area by German leather sofas and a modern coffee table made of granite. In her glass cabinet, artifacts from her world travels were gradually displacing the porcelain figurines, though they were still anchored in place by lace doilies. In the early 2000s, Anna showed me around the growing neighborhood where their neighbors included the star of the city's professional women's handball team, a former Party secretary of the town, and a truck driver. She commented that this was where Dunaújváros's middle class was moving, pointedly using the term "middle class" (középosztály) rather than polgár.

In the 2000s, all three of these families were firmly ensconced in their family houses, but had also acquired apartments for their grown children - not in Dunaújváros, but in the capital city of Budapest. Eszter and Károly, faced with an "empty nest" just a few years into living in their large house, decided to have another child and are raising him in what they imagine to be the standards of a European middle-class citizen. Anna, having retired from her official position, acts as a consultant to her husband's privatizing business and "escapes" the suburban life as often as she can. She continues to travel extensively and collect objects to bring back and display at home. She also now has an apartment in Budapest so she can follow her polgári cultural pursuits, of attending the theater and going to museums. She furnished the bedroom of this apartment with exotic hardwoods and décor from Bali, and the living area in a "retro" design. While her sense of self as a member of a polgári intelligentsia has remained intact, it is no longer materialized in inherited artifacts from the past. 
While polgári furnishings came to embody an idealized polgár sensibility during the socialist decades, it has lost this aura in the 2000s. Indeed, a home furnishing magazine launched in 2001 by the name of Polgári Otthon ("polgári home"), is focused on modern design and stately elegance and rarely features interiors with antique furnishing. For example, in an issue from 2008, the only interior so furnished is that of the celebrity guest, a pop star who recently moved to a nagypolgári (haute bourgeois) villa apartment with a private garden that "measures up to her demands" (Szendi Horváth, 2008, 71). Instead of connecting one's sense of self to the quality craftsmanship and values of an imagined Hungarian polgári past, the criteria for membership in such a class has become far more diffuse, and in a sense, far more challenging. Now one is to craft one's home environment to express individual eclecticism, imagination and at the same time "elegant" good taste through the myriad and ever changing possibilities of modern lifestyle consumption.

\section{References}

Auslander, Leora (1996) Taste and Power: Furnishing Modern France (Berkeley: University of California Press).

Auslander, Leora (2001) 'National Taste?' Citizenship Law, State Form, and Everyday Aesthetics in Modern France and Germany, 1920-1940' in M. Daunton and M. Hilton (eds) The Politics of Consumption: Material Culture and Citizenship in Europe and America (Oxford: Berg Press).

Baló, Júlia (1993) 'Polgári lakás - ma’ (Bourgeois apartment - today) Lakáskultúra, Vol. 28, 29-31. (Budapest: Axel Springer-Budapest Kft.)

Bánkuti, Gábor (ed.) (1958) A lakás (Budapest: Közgazdasági és Jogi Könyvkiadó).

Bars, S. (1963) 'Modern Apartment, Modern Furniture: The New Art of Home Furnishing. The Apartment of Today's Person: What it Should and Shouldn't Have' Dunaújvárosi Hirlap.

Bodnár, Judit (2007) 'Becoming Bourgeois: (Postsocialist) Utopias of Isolation and Civilization' in M. Davis and D. B. Monk (eds) Evil Paradises: Dreamworlds of Neoliberalism (New York, NY: The New Press), 140-51.

Boorstin, Daniel J. (1991 [1974]) Az amerikaiak (The Americans) (Budapest: Gondolat).

Bourdieu, Pierre (1977) Outline of a Theory of Practice (Cambridge: Cambridge University Press).

Bourdieu, Pierre (1984 [1979]) Distinction: A Social Critique of the Judgement of Taste. R. Nice, transl. (Cambridge, MA: Harvard University Press).

Bren, Paulina (2002) 'Weekend Getaways: The Chata, The Tramp, and the Politics of Private Life in Post-1968 Czechoslovakia' in D. Crowley and S. E. Reid (eds) Socialist Spaces: Sites of Everyday Life in the Eastern Bloc (Oxford: Berg Press), 123-40.

Buchowski, Michal (2008) 'The Enigma of the Middle Class: A Case Study of Enterpreneurs in Poland' in I. W. Schroder and A. Vonderau (eds) Changing Economies and Changing Identities in Postsocialist Eastern Europe (Berlin: LIT Verlag), 47-74.

Caldwell, Melissa (2011) Dacha Idylls: Living Organically in Russia's Countryside (Berkeley: University of California Press).

Crowley, David and Susan E. Reid (2000) 'Introduction. Style and Socialism: Modernity and Material Culture in Post-War Eastern Europe' in S. E. Reid and D. Crowley (eds) Style and Socialism: Modernity and Material Culture in Post-War Eastern Europe (Oxford: Berg), 1-24. 
D. É. (1967) 'Változnak az igények’ Lakáskultúra, Vol. 1, 10-11 (Budapest: A Belkereskedelmi Minisztérium Lakberendezési Bizottsága Folyóirata).

Dessewffy, Tibor (1998) 'Az elkeseredettség másik oldala' (Embitteredness: The other side of the story) Népszabadság.

Fehérvary, Krisztina (2011) 'The Materiality of the New Family House: Postsocialist Fad or Middle-class Ideal?' City and Society Vol. 23, No. 1, 18-41.

Fehérváry, Krisztina (2002) 'American Kitchens, Luxury Bathrooms and the Search for a "Normal" Life in Postsocialist Hungary' Ethnos.

Fél, Edit and Tamás Hofer (1969) Proper Peasants: Traditional Life in a Hungarian Village (Chicago: Aldine Publishing Company).

Ferge, Zsuzsa (1979) A Society in the Making: Hungarian Social and Societal Policy 1945-75 (White Plains, NY: M.E. Sharpe, Inc.).

Ferge, Zsuzsa (1997) 'Polgárosodó Magyarország: Lefokozott szociálpolitika' (Hungarian Embourgeoisement: Dwindling Welfare Politics) 168 Óra, 18-19.

Frykman, Jonas and Orvar Löfgren (1987) Culture Builders: A Historical Anthropology of Middle-Class Life. A. Crozier, transl. (New Brunswick: Rutgers University Press).

Gerő, András (1993) Magyar polgárosodás (Budapest: Atlantisz).

Hanák, Péter (ed.) (1992) Polgári lakáskultúra a századfordulón (Bourgeois Apartment Culture at the Turn of the Century) (Budapest: MTA Történettudományi Intézete).

Jameson, E. A. (1993 [1920]) 'Milliók a semmiből' (Millions out of Nothing) (Budapest: Új Vénusz Lap- és Könyvkiadó; orig. 1920s edition. Nova Irodalmi Intézet).

Konrád, György (1984) Antipolitics. R. E. Allen, transl. (San Diego: Harcourt Brace Jovanovich).

Liechty, Mark (2003) Suitably Modern: Making Middle-Class Culture in a New Consumer Society (Princeton: Princeton Univerity Press).

Losonczi, Ágnes (1977) Az életmód az időben, a tárgyakban, és az értékekben (Budapest: Gondolat).

Lukacs, John (1970) 'The Bourgeois Interior' American Scholar, Vol. 39, No. 4, 616-30.

Lukovits, Judit (1995) ‘A biedermeier vonzásában’ in Lakáskultúra, Vol. 30.

Marosán, György (1994) 'The Business of Business: The New Entrepreneurs in the Making' The Hungarian Quarterly, No. 35(136), 72-8.

Rév, István (1991) 'In Mendacio Veritas' Representations, 35.

S. Nagy, Katalin (1987) Lakberendezési szokások (Homefurnishing Customs) (Budapest: Magvető Kiadó).

S. Nagy, Katalin (1997) 'Fogyasztás és lakáskultúra Magyarországon a hetvenes években' (Consumption and Home Furnishing in Hungary in the 1970s) Replika, Vol. 26, 47-53.

Sasfi, Csaba (1993) 'Polgárosodás’ Replika, 11-12.

Somogyi, Éva (ed.) (1991) Polgárosodás Közép-Európában. Tanulmányok Hanák Péter 70. születésnapjára (Budapest: MTA-TTI Magyar Tudományos Akadémia Történettudományi Intézet).

Századvég (1991) 'Polgárosodás Magyarországon', 2-3.

Szelényi, Iván et al. (1988) Socialist Entrepreneurs: Embourgeoisement in Rural Hungary (Madison: University of Wisconsin Press).

Szendi Horváth, Éva (2008) 'Vendégségben Vincze Lillánál' in Polgári Otthon: lakberendezés, házépités, stílus, elegancia Vol. VII (Budapest: Panoráma Kft.), 68-74.

Veenis, Milena (1999) 'Consumption in East Germany: The Seduction and Betrayal of Things' Journal of Material Culture, Vol. 4, No. 1, 79-112.

Weiner, A. (1985) 'Inalienable Possessions' American Ethnologist, Vol. 12, No. 2.

Wilk, Richard (1999) 'Consuming America' Anthropology Today, Vol. 40, No. 2, 1, 4-5. 